\title{
Enhancement of Shelf Life of Spent Hen Meat Sausages with incorporation of Ginger Extract
}

\author{
Mehraj Uddin Reshi ${ }^{1 *}$, Rumase A. Bhat ${ }^{2}$, Muzamil Rashid Dobi ${ }^{1}$, Raouf Pirzada ${ }^{2}$, \\ Sajad A. Beigh ${ }^{2}$, Wani A. Ahad ${ }^{2}$, Waseem ul Firdos ${ }^{2}$ and Altaf Hussain Malik ${ }^{1}$ \\ ${ }^{1}$ Division of Livestock Products Technology, Faculty of Veterinary Sciences and Animal \\ Husbandry, Shuhama, Alasteng, Ganderbal, SKUAST-Kashmir, India \\ ${ }^{2}$ Faculty of Veterinary Sciences and Animal Husbandry, Shuhama, Alasteng, Ganderbal, \\ SKUAST-Kashmir, India
}

*Corresponding author

A B S T R A C T

\begin{tabular}{|c|c|}
\hline $\begin{array}{l}\text { K e y w o r d s } \\
\text { Sausage, Spent Hen } \\
\text { Meat, Ginger extract, } \\
\text { Quality evaluation. }\end{array}$ & \multirow{3}{*}{$\begin{array}{l}\text { Spent hens being the byproducts of poultry layer industry are available in } \\
\text { abundance. The problem with utilisation of spent hen meat is their } \\
\text { perishability while transporting from one place to another place. So the } \\
\text { present investigation was undertaken to assess the shelf life of spent hen } \\
\text { meat with addition of natural substances like ginger extract so that such } \\
\text { byproducts are utilized as protein source and burden on red meat is } \\
\text { minimized. The parameters determined were physico-chemical, proximate } \\
\text { analysis and sensory evaluation. }\end{array}$} \\
\hline Article Info & \\
\hline & \\
\hline
\end{tabular}

\section{Introduction}

Poultry meat consumption has increased in the country with annual per capita consumption of poultry meat being $1.8 \mathrm{~kg}$ (FAO, 2013). With increasing number of meat eating consumers, the cost of meat and meat products is also increasing. Hence there is a dire need to harvest every source of meat to its fullest especially those which can reduce the cost, maintain the quality and meet the increasing consumer demand of meat. Spent hen is one of such cheaper meat source. India produces 65.45 billion eggs annually (FAO, 2012) hence large no of spent hen layers are available which makes around $8.0 \%$ of total poultry meat in India. The development of comminuted meat products offers an important avenue for the profitable disposal of spent hens. However, meat of spent hen may promote faster oxidation than broiler meat during processing and storage due to higher content of unsaturated fatty acids. Utilization of natural spices and herbs in various forms like powder, extract or essential oils has been well documented for antioxidant properties for inhibiting the growth of many spoilage bacteria and fungi in foods. Due to the adverse side effects of synthetic antioxidant on man, such as mutagenesis and 
carcinogenesis, their use has been limited, while the application of natural antioxidants has been on the rise. Ginger (Zingiber officinale) is one of these traditional folk medicinal plants that have been used over the years. Ginger has active substances that have anti-bacterial, anti-flatulent, antimicrobial, anti-inflammatory, anti-diabetic, anti-spasm, anti-cancer and antioxidative properties (Tepe et al., 2006). Thus the present study was designed towards exploring the effects of incorporation of ginger extract in the spent hen meat sausages with the possible extension of shelf life.

\section{Materials and Methods}

Spent hen meat sausages were prepared as per Reshi et al., (2016) treated with $7.5 \%$ lotus stem. Clean and fresh ginger rhizome was procured from local vegetable market of Srinagar city. Fresh and clean green condiments were procured from local market. Green condiments used in the preparation of sausages consisted of onion and garlic paste in the ratio of 3:2 by weight. Table salt (Tata chemicals Ltd., Mumbai, India) of better quality used in the development of sausages. Low-density polyethylene (LDPE) bags procured from registered dealers were used in the refrigeration storage studies of spent hen meat sausages. The refined mustard vegetable oil was used. The spices used were dried at $60^{\circ} \mathrm{C}$ for 3 hours to remove some moisture and were ground into powder in a grinder. The spices mixed were Aniseed, Black pepper, Cardamom, Cinnamon Cloves, Coriander seeds, Cumin seeds, Red chilies and Turmeric in $\mathrm{g}$ per100 $\mathrm{g}$ respectively as $10,15,5,5,5,20,10$ and 10 to form the spice mixture. Ginger extract preparation was carried out according to the method established by Indu et al., (2006) with slight modifications. Fresh Ginger rhizome was cut in to small pieces after removing the skin of ginger. Ginger pieces were homogenized in the juicer. The extract obtained was sieved through doubled muslin cloth. The shelf life of sausages during refrigeration storage $\left(4 \pm 1^{\circ}\right.$ C) for the period of 15 days was checked. The ginger extract was added at the level of 5\% (T1) and 10\% (T2) replacing equal amount of chilled water and the control (T0) without addition of ginger extract. The physicochemical parameters $(\mathrm{pH}$, moisture, ash, TBARS), Microbiological (TPC, Yeast and Mould and Coliform count) and sensory analysis was done on every $5^{\text {th }}$ day. While as protein, ether extract and crude fibre were estimated on $0^{\text {th }}$ day and $15^{\text {th }}$ day of storage only. Same experiment was repeated three times with every parameter calculated in duplicates. Means and standard errors were calculated for different parameters. Data obtained in the study were analysed statistically on 'SPSS-20.0' software package for statistical analysis as per standard methods (Snedecor and Cochran, 1994). Duplicate samples were drawn for each parameter and the experiment was replicated thrice $(n=6)$.

\section{Results and Discussion}

The physico-chemical properties of ginger extract treated spent hen meat sausages are depicted in table 1 .

The overall mean $\mathrm{pH}$ values during the storage of ginger extract treated sausages were higher than control. Mean $\mathrm{pH}$ of T2 was significantly $(\mathrm{p}<0.05)$ higher than control however, the overall mean $\mathrm{pH}$ of $\mathrm{T} 1$ showed non-significant $(p>0.05)$ difference from T0 and T3. Higher $\mathrm{pH}$ in treated sausages might be due to higher $\mathrm{pH}$ of ginger. The overall mean TBA values of the ginger extract treated sausages were significantly $(\mathrm{p}<0.05)$ lower than control. This can indicate that the ginger extract used as antioxidants was effective in reducing TBARS formation. El-Diwani et al., (2009) reported that the ginger extracts contain bioactive substances such as phenolic 
gingerol related compounds that can inhibit chain reactions during lipid oxidation.

The proximate composition determined in ginger extract treated refrigerated meat is shown table 2 .

The mean moisture content of the ginger extract treated spent hen meat sausages did not differ significantly $(\mathrm{p}<0.05)$ from control. However, with advancement of storage period mean moisture content of control and treated sausages decreased significant $(\mathrm{p}<0.05)$. Decrease in the moisture with advancement in storage period might be due to moisture loss from sausages during storage. The mean protein content of control was higher than ginger extract treated sausages but the differences were non-significant $(\mathrm{p}>0.05)$.

Also within ginger extract treated sausages there was non-significant $(\mathrm{p}>0.05)$ difference in their mean protein contents. However as the storage period progresses the mean crude protein of control and treated sausages on $15^{\text {th }}$ day was significantly higher than the crude protein content of $0^{\text {th }}$ day of storage. During storage period increase in protein content could be attributed to the moisture loss which leads to the concentration of protein content. Statically non-significant $(\mathrm{p}>0.05)$ difference was observed in the mean ether extract content of control and ginger extract treated sausages.

However, with the advancement of storage period significant $(p<0.05)$ increase in the mean ether extract content was observed between $0^{\text {th }}$ and $15^{\text {th }}$ day of storage. Nonsignificant $(p>0.05)$ difference was observed in the mean crude fiber content of treatments and control sausages. However with the advancement of storage period significant $(p<0.05)$ increase in the mean crude fiber content of control and treated sausages was observed. Increased crude fiber might be due to vapour lose during storage which lead to increase in relative crude fiber content. The mean ash content of the ginger extract treated spent hen meat sausages was nonsignificantly ( $\mathrm{p}>0.05)$ higher than control. Also the ash content T2 is non-significantly ( $>0.05$ ) different from $\mathrm{T} 1$.

The mean total plate count of ginger extract treated sausages were significantly $(p<0.05)$ lower than control. Between the treated sausages total plate count of $\mathrm{T} 2$ was significantly $(\mathrm{p}<0.05)$ lower than $\mathrm{T} 1$. Lower count in treated sausages than control might be attributes to the antimicrobial property of ginger extract as reported by many workers (Hindi et al., 2001; Sunilson et al., 2009. Gordon (1996) suggested that the isothiocynates present in ginger can inactivate the extracellular enzymes through the oxidative cleavage of disulphide bonds necessary for survival of various bacteria.

The mean coliform count of ginger extract treated sausages were significantly $(p<0.05)$ lower than control. Between the treated sausages coliform count of $\mathrm{T} 2$ was significantly $(\mathrm{p}<0.05)$ lower than $\mathrm{T} 1$. Lower coliform count in the ginger extract treated sausages might be due to antibacterial property of ginger extract as reported by Chen et al., (1985), James et al., (1999). With the progress in the storage period there was a significant $(p<0.05)$ increase in the mean coliform count of control and treated sausages.

The yeast and Mould counts (YMC) of ginger extract treated sausages were significantly $(p<0.05)$ lower than control however, the yeast and mould count of T1 and T2 did not differ significantly $(\mathrm{p}<0.05)$. Lower yeast and mould count of ginger treated sausages might be due to the antifungal properties of ginger.. Similar results were reported by (Libata, 2010) (Table 3). 
Table.1 Effect of incorporation of different concentrations of ginger extract on $\mathrm{pH}$ and TBA values of spent hen meat sausages during refrigeration

\begin{tabular}{|l|l|l|l|l|l|}
\hline \multirow{2}{*}{ Treatments } & \multicolumn{5}{l}{ Storage period (days) } \\
\cline { 2 - 6 } & 0 & 5 & 10 & 15 & Mean \pm S.E \\
\hline $\mathrm{pH}$ & $6.30^{\mathrm{aA}} \pm 0.01$ & $6.35^{\mathrm{b}} \pm 0.01$ & $6.36^{\mathrm{b}} \pm 0.01$ & $6.41^{\mathrm{c}} \pm 0.01$ & $6.36^{\mathrm{A}} \pm 0.01$ \\
\hline Control & $6.34^{\mathrm{a}} \pm 0.01$ & $6.37^{\mathrm{b}} \pm 0.01$ & $6.37^{\mathrm{a}} \pm 0.01$ & $6.40^{\mathrm{b}} \pm 0.01$ & $6.37^{\mathrm{AB}} \pm 0.01$ \\
\hline T1 & $6.36^{\mathrm{B}} \pm 0.01$ & $6.38 \pm 0.01$ & $6.38 \pm 0.01$ & $6.39 \pm 0.01$ & $6.38^{\mathrm{B}} \pm 0.01$ \\
\hline T2 & $6.36^{\mathrm{b}} \pm 0.01$ & $6.37^{\mathrm{b}} \pm 0.01$ & $6.40^{\mathrm{c}} \pm 0.01$ & \\
\hline Mean \pm S.E & $6.33^{\mathrm{a}} \pm 0.01$ & \multicolumn{7}{l|}{} \\
\hline TBA & $0.08^{\mathrm{bA}} \pm 0.01$ & $0.85^{\mathrm{cA}} \pm 0.01$ & $1.06^{\mathrm{dA}} \pm 0.03$ & $0.68^{\mathrm{A}} \pm 0.06$ \\
\hline T0 (control) & $0.24^{\mathrm{a}} \pm 0.01$ & 0.01 & $0.43^{\mathrm{B}} \pm 0.03$ \\
\hline T1 & $0.23^{\mathrm{a}} \pm 0.01$ & $0.39^{\mathrm{bB}} \pm 0.00$ & $0.51^{\mathrm{C}} \pm 0.01$ & $0.60^{\mathrm{d}} \pm 0.02$ & $0.38^{\mathrm{C}} \pm 0.02$ \\
\hline T2 & $0.22^{\mathrm{a}} \pm 0.01$ & $0.34^{\mathrm{bC}} \pm 0.00$ & $0.43^{\mathrm{cC}} \pm 0.01$ & $0.52^{\mathrm{dC}} \pm 0.01$ & \\
\hline Mean \pm S.E & $0.23^{\mathrm{a}} \pm 0.01$ & $0.44^{\mathrm{b}} \pm 0.02$ & $0.60^{\mathrm{c}} \pm 0.04$ & $0.72^{\mathrm{d}} \pm 0.06$ & \\
\hline
\end{tabular}

Mean \pm SE values bearing different superscripts row-wise (small letters) and same superscripts column-wise (capital letters) differ significantly $(\mathrm{P}<0.05) \mathrm{n}=6$

Table.2 Effect of different concentrations of ginger extract on the proximate composition of spent hen meat sausages during refrigeration storage $\left(4 \pm 1^{\circ} \mathrm{C}\right)$

\begin{tabular}{|c|c|c|c|c|c|}
\hline \multirow[t]{2}{*}{ Treatments } & \multicolumn{5}{|c|}{ Storage period days } \\
\hline & 0 & 5 & 10 & 15 & Mean \pm S.E \\
\hline \multicolumn{6}{|l|}{ Moisture } \\
\hline T0 & $60.74^{\mathrm{a}} \pm 0.21$ & $60.15^{\mathrm{ab}} \pm 0.32$ & $59.27^{\mathrm{bc}} \pm 0.31$ & $58.39^{\mathrm{c}} \pm 0.28$ & $59.64 \pm 0.23$ \\
\hline $\mathrm{T} 1$ & $60.84^{\mathrm{a}} \pm 0.30$ & $60.63^{\mathrm{a}} \pm 0.31$ & $59.44^{\mathrm{b}} \pm 0.29$ & $58.52^{\mathrm{c}} \pm 0.28$ & $59.86 \pm 0.24$ \\
\hline $\mathrm{T} 2$ & $60.87^{\mathrm{a}} \pm 0.37$ & $60.68^{\mathrm{ab}} \pm 0.36$ & $59.78^{\mathrm{bc}} \pm 0.33$ & $58.99^{\mathrm{c}} \pm 0.18$ & $60.08 \pm 0.22$ \\
\hline Mean \pm S.E & $60.82^{\mathrm{a}} \pm 0.16$ & $60.49^{\mathrm{a}} \pm 0.19$ & $59.50^{\mathrm{b}} \pm 0.18$ & $58.63^{\mathrm{c}} \pm 0.15$ & \\
\hline \multicolumn{6}{|l|}{\begin{tabular}{|l|l} 
Ash \\
\end{tabular}} \\
\hline $\mathrm{T} 0$ & $3.12^{\mathrm{a}} \pm 0.01$ & $3.12^{\mathrm{a}} \pm .01$ & $3.16^{\mathrm{b}} \pm 0.01$ & $3.21^{\mathrm{c}} \pm 0.01$ & $3.15 \pm 0.01$ \\
\hline $\mathrm{T} 1$ & $3.13^{\mathrm{a}} \pm 0.01$ & $3.14^{\mathrm{a}} \pm .01$ & $3.17^{\mathrm{a}} \pm 0.01$ & $3.21^{\mathrm{b}} \pm 0.02$ & $3.16 \pm 0.01$ \\
\hline $\mathrm{T} 2$ & $3.14^{\mathrm{a}} \pm 0.01$ & $3.15^{\mathrm{ab}} \pm .01$ & $3.18^{\mathrm{bc}} \pm 0.01$ & $3.22^{\mathrm{c}} \pm 0.02$ & $3.17 \pm 0.01$ \\
\hline Mean \pm S.E & $3.13^{\mathrm{a}} \pm 0.01$ & $3.14^{\mathrm{a}} \pm .01$ & $3.17^{\mathrm{b}} \pm 0.01$ & $3.21^{\mathrm{c}} \pm 0.01$ & \\
\hline \multicolumn{6}{|l|}{ Crude protein } \\
\hline $\begin{array}{ll}\text { T0 } \\
\end{array}$ & $14.53^{\mathrm{a}} \pm 0.06$ & N.D & N.D & $14.84^{\mathrm{b}} \pm 0.03$ & $14.69 \pm 0.06$ \\
\hline $\mathrm{T} 1$ & $14.51^{\mathrm{a}} \pm 0.06$ & N.D & N.D & $14.74^{\mathrm{b}} \pm 0.04$ & $14.63 \pm 0.05$ \\
\hline $\mathrm{T} 2$ & $14.47^{\mathrm{a}} \pm 0.06$ & N.D & N.D & $14.72^{\mathrm{b}} \pm 0.05$ & $14.60 \pm 0.05$ \\
\hline Mean \pm S.E & $14.50^{\mathrm{a}} \pm 0.03$ & N.D & N.D & $14.77^{\mathrm{b}} \pm 0.03$ & \\
\hline \multicolumn{6}{|l|}{ Ether extract } \\
\hline T0 & $19.27^{\mathrm{a}} \pm 0.03$ & N.D & N.D & $19.71^{\mathrm{b}} \pm 0.01$ & $19.48 \pm 0.07$ \\
\hline $\mathrm{T} 1$ & $19.21^{\mathrm{a}} \pm 0.03$ & N.D & N.D & $19.72^{\mathrm{b}} \pm 0.02$ & $19.46 \pm 0.08$ \\
\hline $\mathrm{T} 2$ & $19.19^{\mathrm{a}} \pm 0.02$ & N.D & N.D & $19.69^{\mathrm{b}} \pm 0.02$ & $19.44 \pm 0.08$ \\
\hline Mean \pm S.E & $19.21^{\mathrm{a}} \pm 0.01$ & N.D & N.D & $19.71^{\mathrm{b}} \pm 0.01$ & \\
\hline \multicolumn{6}{|l|}{ Crude fiber } \\
\hline T0 & $2.38^{\mathrm{a}} \pm 0.00$ & N.D & N.D & $2.57^{\mathrm{b}} \pm 0.00$ & $2.48 \pm 0.01$ \\
\hline $\mathrm{T} 1$ & $2.38^{\mathrm{a}} \pm 0.01$ & N.D & N.D & $2.59^{\mathrm{b}} \pm 0.01$ & $2.49 \pm 0.03$ \\
\hline $\mathrm{T} 2$ & $2.39^{\mathrm{a}} \pm 0.00$ & N.D & N.D & $2.59^{\mathrm{b}} \pm 0.01$ & $2.49 \pm 0.03$ \\
\hline Mean \pm S.E & $2.38^{\mathrm{a}} \pm 0.00$ & N.D & N.D & $2.59^{\mathrm{b}} \pm 0.00$ & \\
\hline
\end{tabular}

Mean \pm SE values bearing different superscripts row-wise (small letters) and same superscripts column-wise (capital letters) differ significantly $(\mathrm{P}<0.05)$

N.D not determined. 
Table.3 Effect of different concentrations of ginger extract on the microbiological properties of spent hen meat sausages during refrigeration storage $\left(4 \pm 1^{\circ} \mathrm{C}\right)$

\begin{tabular}{|c|c|c|c|c|c|}
\hline \multirow[t]{2}{*}{ Treatments } & \multicolumn{5}{|c|}{ Storage period (days) } \\
\hline & 0 & 5 & 10 & 15 & Mean \pm S.E \\
\hline \multicolumn{6}{|c|}{ Total plate count } \\
\hline T0 & $2.12^{\mathrm{aA}} \pm 0.03$ & $2.97^{\mathrm{bA}} \pm 0.01$ & $3.27^{\mathrm{cA}} \pm 0.01$ & $3.39^{\mathrm{dA}} \pm 0.01$ & $2.94^{\mathrm{A}} \pm 0.10$ \\
\hline $\mathrm{T} 1$ & $2.00^{\mathrm{aB}} \pm 0.03$ & $2.53^{\mathrm{bB}} \pm 0.02$ & $2.70^{\mathrm{cB}} \pm 0.02$ & $3.01^{\mathrm{dB}} \pm 0.04$ & $2.56^{\mathrm{B}} \pm 0.08$ \\
\hline $\mathrm{T} 2$ & $1.94^{\mathrm{aB}} \pm 0.03$ & $2.45^{\mathrm{bC}} \pm 0.02$ & $2.69^{\mathrm{cB}} \pm 0.03$ & $2.79^{\mathrm{dC}} \pm 0.06$ & $2.47^{\mathrm{C}} \pm 0.07$ \\
\hline Mean \pm S.E & $2.02^{\mathrm{a}} \pm 0.03$ & $2.65^{\mathrm{b}} \pm 0.06$ & $2.89^{\mathrm{c}} \pm 0.07$ & $3.06^{\mathrm{d}} \pm 0.06$ & \\
\hline \multicolumn{6}{|c|}{ Coliform count } \\
\hline T0 & $1.38^{\mathrm{aA}} \pm 0.06$ & $1.88^{\mathrm{bA}} \pm 0.03$ & $1.90^{\mathrm{bA}} \pm 0.03$ & $2.22^{\mathrm{c}} \pm 0.03$ & $1.84^{\mathrm{A}} \pm 0.07$ \\
\hline $\mathrm{T} 1$ & $1.28^{\mathrm{aAB}} \pm 0.06$ & $1.77^{\mathrm{bAB}} \pm 0.04$ & $1.83^{\mathrm{bAB}} \pm 0.02$ & $2.15^{\mathrm{c}} \pm 0.04$ & $1.76^{\mathrm{B}} \pm 0.07$ \\
\hline $\mathrm{T} 2$ & $1.19^{\mathrm{aB}} \pm 0.04$ & $1.67^{\mathrm{bB}} \pm 0.03$ & $1.74^{\mathrm{bB}} \pm 0.02$ & $2.11^{\mathrm{c}} \pm 0.03$ & $1.68^{\mathrm{C}} \pm 0.07$ \\
\hline Mean \pm S.E & $1.28^{\mathrm{a}} \pm 0.03$ & $1.77^{\mathrm{b}} \pm 0.03$ & $1.83^{\mathrm{b}} \pm 0.02$ & $2.16^{\mathrm{c}} \pm 0.04$ & \\
\hline \multicolumn{6}{|c|}{ Yeast and mould count } \\
\hline T0 & $0.86^{\mathrm{a}} \pm 0.03$ & $1.47^{\mathrm{bA}} \pm 0.10$ & $1.54^{\mathrm{bA}} \pm 0.10$ & $1.90^{\mathrm{cA}} \pm 0.08$ & $1.44^{\mathrm{A}} \pm 0.09$ \\
\hline $\mathrm{T} 1$ & $0.73^{\mathrm{a}} \pm 0.04$ & $1.14^{\mathrm{bB}} \pm 0.05$ & $1.20^{\mathrm{bB}} \pm 0.04$ & $1.66^{\mathrm{cB}} \pm 0.05$ & $1.18^{\mathrm{B}} \pm 0.07$ \\
\hline $\mathrm{T} 2$ & $0.70^{\mathrm{a}} \pm 0.03$ & $1.11^{\mathrm{bB}} \pm 0.05$ & $1.16^{\mathrm{bB}} \pm 0.05$ & $1.55^{\mathrm{cB}} \pm 0.03$ & $1.13^{\mathrm{B}} \pm 0.07$ \\
\hline Mean \pm S.E & $0.77^{\mathrm{a}} \pm 0.03$ & $1.24^{\mathrm{b}} \pm 0.06$ & $1.30^{\mathrm{b}} \pm 0.06$ & $1.70^{\mathrm{c}} \pm 0.05$ & \\
\hline
\end{tabular}

Table.4 Effect of different concentrations of ginger extract on the sensory attributes of spent hen meat sausages during refrigeration storage $\left(4 \pm 1^{\circ} \mathrm{C}\right)$

\begin{tabular}{|c|c|c|c|c|c|}
\hline \multirow[t]{3}{*}{ Treatments } & \multicolumn{5}{|c|}{ Storage period (days) } \\
\hline & 0 & 5 & 10 & 15 & Mean \pm S.E \\
\hline & \multicolumn{5}{|c|}{ Appearance score } \\
\hline T0 & $7.38^{\mathrm{a}} \pm 0.13$ & $7.14^{\mathrm{ab}} \pm 0.13$ & $6.86^{\mathrm{bc}} \pm 0.14$ & $6.57^{\mathrm{c}} \pm 0.11$ & $6.99 \pm 0.068$ \\
\hline $\mathrm{T} 1$ & $7.48^{\mathrm{a}} \pm 0.13$ & $7.24^{\mathrm{ab}} \pm 0.12$ & $6.95^{\mathrm{bc}} \pm 0.13$ & $6.76^{\mathrm{c}} \pm 0.12$ & $7.11 \pm 0.09$ \\
\hline $\mathrm{T} 2$ & $7.48^{\mathrm{a}} \pm .13$ & $7.29^{\mathrm{ab}} \pm 0.12$ & $7.05^{\mathrm{bc}} \pm 0.16$ & $6.76^{\mathrm{c}} \pm 0.12$ & $7.14 \pm 0.10$ \\
\hline Mean \pm S.E & $7.44^{\mathrm{a}} \pm 0.13$ & $7.22^{\mathrm{a}} \pm 0.13$ & $6.95^{\mathrm{b}} \pm 0.12$ & $6.70^{\mathrm{c}} \pm 0.15$ & \\
\hline \multicolumn{6}{|l|}{ Flavour score } \\
\hline T0 & $7.33^{\mathrm{aA}} \pm 0.12$ & $7.00^{\mathrm{abA}} \pm 0.12$ & $6.76^{\mathrm{bc}} \pm 0.12$ & $6.57^{\mathrm{c}} \pm 0.11$ & $6.92^{\mathrm{A}} \pm 0.09$ \\
\hline T1 & $7.38^{\mathrm{aA}} \pm 013$ & $7.10^{\mathrm{abAB}} \pm 0.10$ & $6.90^{\mathrm{bc}} \pm .14$ & $6.71^{\mathrm{c}} \pm 0.11$ & $7.02^{\mathrm{A}} \pm 0.06$ \\
\hline $\mathrm{T} 2$ & $6.95^{\mathrm{aB}} \pm 0.15$ & $6.71^{\mathrm{abB}} \pm 0.14$ & $6.52^{\mathrm{b}} \pm 0.13$ & $6.38^{\mathrm{b}} \pm 0.11$ & $6.64^{\mathrm{B}} \pm 0.07$ \\
\hline Mean \pm S.E & $7.22^{\mathrm{a}} \pm 0.08$ & $6.94^{\mathrm{b}} \pm 0.07$ & $6.73^{\mathrm{c}} \pm 0.07$ & $6.56^{\mathrm{c}} \pm 0.06$ & \\
\hline \multicolumn{6}{|c|}{ Juiciness score } \\
\hline T0 & $7.19^{\mathrm{a}} \pm 0.15$ & $7.00^{\mathrm{a}} \pm 0.14$ & $6.81^{\mathrm{ab}} \pm 0.11$ & $6.48^{\mathrm{b}} \pm 0.13$ & $6.87 \pm 0.07$ \\
\hline $\mathrm{T} 1$ & $7.29^{\mathrm{a}} \pm 0.16$ & $7.10^{\mathrm{a}} \pm 0.14$ & $6.95^{\mathrm{ab}} \pm 0.13$ & $6.62^{\mathrm{b}} \pm 0.11$ & $6.99 \pm 0.07$ \\
\hline $\mathrm{T} 2$ & $7.33^{\mathrm{a}} \pm 0.14$ & $7.10^{\mathrm{ab}} \pm 0.15$ & $6.86^{\mathrm{bc}} \pm 0.16$ & $6.62^{c} \pm 0.12$ & $6.98 \pm 0.08$ \\
\hline Mean \pm S.E & $7.27^{\mathrm{a}} \pm 0.09$ & $7.06^{\mathrm{ab}} \pm .08$ & $6.87^{\mathrm{b}} \pm 0.08$ & $6.57^{c} \pm 0.53$ & \\
\hline \multicolumn{6}{|l|}{ Texture score } \\
\hline T0 & $7.29^{\mathrm{a}} \pm 0.17$ & $6.95^{\mathrm{a}} \pm 0.13$ & $6.71^{\mathrm{ab}} \pm 0.11$ & $6.52^{\mathrm{c}} \pm 0.11$ & $6.87 \pm 0.07$ \\
\hline $\mathrm{T} 1$ & $7.43^{\mathrm{a}} \pm 0.14$ & $7.14^{\mathrm{a}} \pm 0.11$ & $6.90^{\mathrm{b}} \pm 0.15$ & $6.71^{\mathrm{c}} \pm 0.11$ & $7.05 \pm 0.07$ \\
\hline $\mathrm{T} 2$ & $7.38^{\mathrm{a}} \pm 0.14$ & $7.10^{\mathrm{a}} \pm 0.16$ & $6.90^{\mathrm{b}} \pm 0.13$ & $6.67^{\mathrm{c}} \pm 0.11$ & $7.05 \pm 0.07$ \\
\hline Mean \pm S.E & $7.37^{\mathrm{a}} \pm 0.09$ & $7.06^{\mathrm{a}} \pm 0.08$ & $6.84^{\mathrm{b}} \pm 0.07$ & $6.63^{\mathrm{c}} \pm 0.06$ & \\
\hline \multicolumn{6}{|c|}{ Overall palatability } \\
\hline T0 & $7.24^{\mathrm{a}} \pm 0.14$ & $7.10^{\mathrm{ab}} \pm 0.12$ & $6.86^{\mathrm{bc}} \pm 0.13$ & $6.57^{\mathrm{c}} \pm 0.11$ & $6.94^{\mathrm{A}} \pm 0.10$ \\
\hline $\mathrm{T} 1$ & $7.48^{\mathrm{a}} \pm 0.11$ & $7.24^{\mathrm{ab}} \pm 0.12$ & $7.06^{\mathrm{bc}} \pm 0.15$ & $6.76^{\mathrm{c}} \pm 0.10$ & $7.14^{\mathrm{B}} \pm 0.11$ \\
\hline $\mathrm{T} 2$ & $7.29^{\mathrm{a}} \pm 0.10$ & $7.10^{\mathrm{ab}} \pm 0.14$ & $6.90^{\mathrm{bc}} \pm 0.15$ & $6.67^{\mathrm{c}} \pm 0.11$ & $6.99^{\mathrm{AB}} \pm 0.09$ \\
\hline Mean \pm S.E & $7.33^{\mathrm{a}} \pm 0.13$ & $7.14^{\mathrm{ab}} \pm 0.12$ & $6.95^{\mathrm{b}} \pm 0.10$ & $6.67^{\mathrm{c}} \pm 0.11$ & \\
\hline
\end{tabular}


The overall mean appearance scores of ginger extract treated sausages were higher than control, however the non- significant $(p>0.05)$ difference was reported between control, and treated sausages. During storage period the overall mean appearance score of control and ginger extract treated spent hen meat sausages showed significant decrease with increase in storage days. The decrease in mean appearance score during storage could be due to surface dehydration, lose of volatile components and lipid oxidation causing non-enzymatic browning in the sausages in aerobic conditions of storage. Naveena et al., (2004) also reported increase in appearance score of buffalo meat incorporated with ginger. The overall mean flavour score of $\mathrm{T} 1$ was non-significantly ( $>>0.05$ ) higher than control (Table 4). While as the mean flavour score of T2 was significantly $(\mathrm{p}<0.05)$ lower than $\mathrm{T} 1$ and control sausages. Increase in the flavour score of sausages at the addition of lower concentrations of ginger extract treated might be due to flavour producing reaction which occurred during cooking. Similar results were reported by (Labell, 1987) in the poultry meat treated with $2 \%$ ginger powder. However, the decrease in flavour score with the addition of higher concentration of ginger extract might be due to bitterness of ginger extract which out shades its initial flavour improving effect. During storage period the overall mean flavour score of control and ginger extract treated spent hen meat sausages showed significant decrease with increase in storage period. The decrease in mean flavour score of sausages during storage could be due to microbial growth, oxidative changes and lose of volatile flavour components during aerobic conditions of storage. The overall mean juiciness score of ginger extract treated sausages was higher than control, but the differences were non- significant $(p>0.05)$. Improvement in juiciness might be due to retention of more moisture content by treated sausages over control. During storage the significant overall decrease was reported in mean juiciness score of control and treated spent hen meat sausages. Improvements in juiciness score are in agreement with results of the Zia-ur-Rehman et al., (2003). Decrease in juiciness with progress in storage might be due to moisture loss during aerobic storage of sausages. The overall mean texture score of ginger extract treated sausages was higher than control, but the differences were nonsignificant $(p>0.05)$. Decrease in the texture score during storage might be due to the breakdown of fat and protein complex vedamurthy (1998). During storage period general decrease was reported in the overall mean texture score of control and ginger extract treated spent hen meat sausages. Decrease in the texture score during storage might be due to the breakdown of fat and protein complex. The mean overall acceptability score of the T1 was significantly $(\mathrm{p}<0.05)$ higher than control, but a non-significant $\quad(p>0.05)$ difference was reported with T2. Our results were in consistent with the results of Anandh (2013) in ginger extract treated buffalo tripe. However overall acceptability score of sausages with higher concentrations of ginger extract, T2 decreased and was non-significant ( $p>0.05$ ) lower than $\mathrm{T} 1$ sausages. Decrease in overall acceptability score at higher concentration maybe due to drastic decrease in the flavour score at higher concentration. During storage period an overall decrease was reported in the overall mean overall acceptability scores of control and ginger extract treated spent hen meat sausages. The decrease in overall acceptability of sausages with storage might be due to the changes like lipid oxidation, protein degeneration, moisture lose and microbial growth.

The refrigeration storage $\left(4 \pm i^{\circ} \mathrm{C}\right)$ of $7.5 \%$ lotus stem added spent hen meat sausages with the incorporation of different levels of ginger extract improved the shelf life of sausages as evaluated in terms of physico-chemical properties ( $\mathrm{pH}$ and TBA), microbiological (total plat count, coliform count and yeast and mould count) and sensory attributes could remain fairly acceptable upto 15 days under refrigeration storage. Thus usage of ginger extract in the development of value added comminuted meat products from spent hen meat 
like sausages proves a technically viable option for enhancing the utilization of spent hen meat.

\section{References}

Anandh, M.A. 2013. Effect of different tenderizers on tenderness and quality of buffalo tripe. Asian Journal of Dairy and Food Research. 32 (2): 144-148.

El-Diwani, G., El-Rafie, S. and Hawash, S. 2009. Protection of biodiesel and oil from degradation by natural antioxidants of Egyptian Jatropha. International Journal Environment Science Technology. 6 (3): $369-378$.

FAO. 2012. Food and Agriculture Organization Statistical Database. Food and Agriculture Organization of United Nations.

FAO. 2013. Food and Agriculture Organization Statistical Database. Food and Agriculture Organization of United Nations.

Gordon, M. H. 1996. The mechanism of antioxidant action in vitro. In Food Antioxidant Ed by Hudson BJF, Elsevier Applied Science, New York. p1-18.

Hindi, N.K.K., Al-Mahdi, Z.K.A. and Chabuck, Z.A.G. 2001. Antibacterial activity of the aquatic extractof fresh, dry powder ginger, apple vinegar extract of fresh ginger and crud oil of Ginger (zingiber officinale) against different types of bacteria in hilla city, iraq. International Journal Of Pharmacy And Pharmaceutical Sciences. 6(5): 414-417

Indu, M.N., Hatha, A.A.M., Abirosh, C., Hasha, U. and Vivekanandan, G. 2006. Antimicrobial efficiency of Escherichia coli, Salmonella, Listeria monocytogenes and Aeromonas hydrophilla. Brazilian Journal of Microbiology. 37: 153-158.

Labell, F. 1987. Functional flavor systems improve quality of microwave meats. Poultry Food Processing-USA 48: 63-64.

Libata, I.G., Samuel, O.F., Folake, O.P., Oluwaseun, A.C. and onyebuchi, N.E. 2010. The effect of different concentrations of ginger on the quality of smoked dried catfish (Clarias gariepinus). Nature and Science. 8(4): 59-63

Naveena, B.M., Mendiratta, S.K. and Anjaneyulu, A.S.R. 2004. Tenderization of buffalo meat using plant proteases from Cucumis trigonus Roxb (Kachri) and Zingiber officinale roscoe (Ginger rhizome). Meat Science. 68: 363-369.

Reshi (2016). Utilisation of spent hen meat for development of some value added products. M.V.Sc Thesis. SKUAST-K. p: 34-35.

Snedecor, G. W. and Cochran, W. G. 1994. Statistical methods, 1st edn. Ch. 12 and 13. East West press.

Sunilson, J.A.J., Suraj, R., Rejitha, G., Anandarajagopal, K., Kumari, A. V. A. G. and Promwichit, P. 2009. In vitro antimicrobial evaluation of Zingiber officinale, Curcuma longa Alpinia and galangal extracts as natural food preservatives. American Journal of Food Technology. 4(5):192-200.

Tepe, B., Sokmen, M., Akpulat, H.A. and Sokmen, A. 2006. Screening of the antioxidant potentials of six Salvia species from Turkey. Food Chemistry, 95: 200204.

Vedamurthy, C.B. 1998. Utilization of collagen isolated from skin for the production of low fat sausages M.V.Sc. Thesis submitted to deemed university IVRI, Izatnagar.

Zia-ur-Rehman, Salariya, A.M. and Habib, F. 2003. Antioxidant activity of ginger extract in sunflower oil. Journal of the Science of Food and Agriculture. 83: 624-629.

\section{How to cite this article:}

Mehraj Uddin Reshi, Rumase A. Bhat, Muzamil Rashid Dobi, Raouf Pirzada, Sajad A. Beigh, Wani A. Ahad, Waseem ul Firdos and Altaf Hussain Malik. 2017. Enhancement of Shelf Life of Spent Hen Meat Sausages with Incorporation of Ginger Extract. Int.J.Curr.Microbiol.App.Sci. 6(11): 1124-1130. doi: https://doi.org/10.20546/ijcmas.2017.611.133 